\title{
PENGARUH EFEKTIVITAS PENEMPATAN KERJA DAN KARAKTERISTIK PEKERJAAN TERHADAP MOTIVASI BERPRESTASI SERTA DAMPAKNYA PADA KINERJA PEGAWAI DINAS PENDIDIKAN KABUPATEN LABUHANBATU
}

\author{
Ade Parlaungan Nasution \\ Dosen Tetap Sekolah Tinggi Ilmu Ekonomi (STIE) Labuhanbatu
}

\begin{abstract}
ABSTRAK
Dalam mencapai tujuan organisasi yang berkaitan dengan kinerja harus didukung oleh sumber daya manusia yang terampil dan handal, perlu adanya suatu perencanaan dalam menentukan pegawai yang akan mengisi posisi pekerjaan yang ada dalam organisasi. Tercapainya kinerja organisasi bergantung pada lingkungan kerja, efektivitas penempatan sumber daya manusia dan karakteristik pekerjaan pada posisi jabatan tersebut. Penelitian ini bertujuan untuk mengetahui dan menganalisis pengaruh langsung efektivitas penempatan kerja dan karakteristik pekerjaan terhadap kinerja pegawai. Untuk mengetahui dan menganalisis pengaruh langsung efektivitas penempatan kerja dan karakteristik pekerjaan terhadap lingkungan kerja. Untuk mengetahui dan menganalisis pengaruh tidak langsung efektivitas penempatan kerja dan karakteristik pekerjaan terhadap kinerja pegawai melalui variabel intervening lingkungan kerja. Populasi yang dimaksudkan pada penelitian ini pegawai Dinas Pendidikan Kabupaten Labuhanbatu sebanyak 40 responden dengan teknik pengambilan sampel menggunakan sampel jenuh. Teknik untuk mengumpulkan data primer antara lain observasi, wawancara dan penyebaran kuesioner. Teknik analisis data penelitian yaitu model analisis jalur dengan bantuan software SPSS dan AMOS. Hasil penelitian ini membuktikan bahwa efektivitas penempatan kerja dan karakteristik pekerjaan berpengaruh langsung terhadap lingkungan kerja, efektivitas penempatan kerja dan karakteristik pekerjaan secara tidak langsung berpengaruh terhadap kinerja pegawai dan terdapat pengaruh langsung antara efektivitas penempatan kerja dan karakteristik pekerjaan terhadap lingkungan kerja sebagai intervening serta pengaruh langsung terhadap kinerja pegawai.
\end{abstract}

Kata Kunci : Penempatan Kerja, Karakteristik Pekerjaan, Kepuasan Kerja, Kinerja.

\section{PENDAHULUAN}

output yang maksimal. Keberhasilan suatu organisasi sangat dipengaruhi oleh kinerja individu pegawainya. Setiap organisasi maupun perusahaan akan selalu berusaha untuk meningkatkan kinerja pegawai, dengan harapan apa yang menjadi tujuan organisasi akan tercapai.Organisasi menempuh beberapa cara untuk meningkatkan kinerja pegawai, misalnya melalui pendidikan, pelatihan, pemberian kompensasi yang Keberadaan sumber daya manusia dalam suatu organisasi memegang peranan yang sangat penting. Potensi setiap sumber daya manusia yang ada dalam organisasi harus dapat dimanfaatkan dengan sebaik-baiknya sehingga mampu memberikanlayak, menciptakan lingkungan kerja yang kondusif, kesempatan pengembangan karier maupun pemberian motivasi. Melalui prosesproses tersebut, pegawai diharapkan akan lebih memaksimalkan tanggung jawab atas 
pekerjaan mereka karena para pegawai telah terbekali oleh pendidikan dan pelatihan yang tentu berkaitan dengan implementasi kerja mereka.

Dinas Pendidikan merupakan unsur pelaksana otonomi daerah di bidang pendidikan dasar, menengah kejuruan, pendidikan non formal serta pembinaan pemuda dan olahraga. Salah satu pelaksana otonomi daerah di bidang pendidikan daerah berdasarkan asas otonomi dan tugas pembantuan, sesuai dengan PERDA No. $10 \quad$ Tahun 2008 tentang pembentukan, Susunan, Kedudukan dan Tugas PokokDinasDaerah.Keberhasilan

Dinas Pendidikan

Kabupaten Labuhanbatu dalam merencanakan program untuk menunjang mengembangkan watak bangsa yang bermartabat dalam rangka mencerdaskan kehidupan bangsa, bertujuan untuk berkembangnya potensi peserta didik agar menjadi manusia yang beriman dan bertakwa kepada Tuhan Yang Maha Esa, berakhlak mulia, sehat, berilmu, cakap, kreatif, mandiri dan menjadi warga Negara yang demokratis serta bertanggung jawab memerlukan sumber daya manusia yang unggul sesuai jabatan.

Dalam suatu organisasi pemerintahan, sumber daya manusia atau yang disebut dengan pegawai, adalah salah satu unsur yang paling penting yang harus diperhatikan. Setiap istansi pemerintahan dituntut untuk dapat mengoptimalkan sumber daya manusia tersebut guna mencapai tujuan organisasi.

Sumberdaya manusia merupakan penggerak dan penentu jalannya suatu organisasi, hal itu dikarenakan pegawai mempunyai peranan yang strategis didalam organisasi yaitu sebagai pemikir, perencana, dan pengendali aktivitas organisasi. Maka dari itu, instansi benarbenar dituntut untuk mampu memberikan arahan yang positif kepada seluruh pegawai demi tercapainya tujuan organisasi dan mampu meningkatkan kinerja pegawai.

Efektifnya penempatan pegawai dalam suatu instansi pemerintahan diharapkan sesuai dengan kemampuan yang dimiliki individu. Karena tanpa adanya penempatan yang sesuai dengan bidangnya, maka dapat menimbulkan permasalahan baru dalam organisasi tersebut. Kita juga sering mendengar bahwa terdapat banyak kasus Pegawai Negeri Sipil yang bekerja dan ditempatkan tidak sesuai dengan bidangnya. Padahal, posisi yang dimaksud harus ditempati oleh seorang pegawai yang sudah memiliki kemampuan khusus dan sudah mengikuti pelatihan sebelumnya.

MenurutIsdarmadi (2002), membuktikan penelitiannya bahwa efektivitas penempatan kerja berpengaruh positif dan signifikan terhadap kinerja pegawai. Hasil penelitian ini jelas memberikan gambaran penting kepada lembaga pemerintahan pusat dan daerah bahwakeberhasilanpembangunan nasional sangat ditentukan oleh keberhasilan aparatur negara dalam melaksanakan tugasnya, terutama dari ketepatan penempatan pegawai pada posisinya.

Guna mencapai tujuan dan sasaran yang telah ditetapkan dalam suatu organisasi dalam periode tertentu, kinerja pegawai dapat dipengaruhi oleh karakteristik pekerjaan. Karakteristik pekerjaan pada beberapa instansi memiliki peran penting untuk mewujudkan tujuan-tujuan yang akan dicapai, peranan karakteristik pekerjaan terhadap kinerja seorang pegawai yakni adanya pemahaman pegawai terhadap isi/tugas di dalam pekerjaannya. Menurut Restanto (2008) karakteristik pekerjaan adalah atribut-atribut tugas bersifat yang ada di dalam pekerjaan. Selanjutnya menurut Restanto (2008) karakteristik pekerjaan sebagai isi pekerjaan yang dirasakan pegawai sebagai pemegang pekerjaan.

Sebagaimana dalam pelaksanaan tugas, fungsi dan tanggung jawab sebagai pegawai negeri sipil, setiap pegawai seharusnya dapat melaksanakan tugas dan pekerjaan sesuai dengan penuh rasa tanggung jawab serta mengikuti atau melaksanakan peraturan yang berlaku. Penempatan pegawai yang efektif dan karakteristik pekerjaan yang jelas dalam suatu organisasi 
secara tidak langsung berdampak pada peningkatan motivasi berprestasi. Menurut Soares (2010) menyatakan bahwa secara tidak langsung efektivitas penempatan kerja dan karakteristik pekerjaan berpengaruh terhadap motivasi berprestasi.

Menurut Sumantri (2001) motivasi berprestasi merupakan bentuk kepedulian terhadap kompetisi dan keinginan untuk hidup berdasarkan suatu standar keunggulan dapat berupa prestasi yang dimiliki sendiri ataupun prestasi orang lain. Rendahnya motivasi berprestasi pegawai dalam suatu organisasi atau instansi Dinas Pendidikan Kabupaten Labuhanbatu dapat diukur dari tingkat kehadiran pegawai dalam beberapa periode, seperti masih ditemukannya

pegawai yang datang terlambat ke kantor, pegawai pulang lebih awal, tidak mengisi absensi jika sudah di kantor dan pegawai yang mangkir dari pekerjaan tanpa keterangan.

Berangkat dari uraian latar belakang dengan fenomena dan justifikasi penelitian pendukung, penulis tertarik untuk mengkaji secara empiris permasalahan yang terjadi Dinas Pendidikan Kabupaten Labuhanbatu khususnya mengenai pengaruh efektivitas penempatan kerja dan karakteristik pekerjaan terhadap motivasi berprestasi serta dampaknya pada kinerja pegawai dalam rangka pembangunan sumber daya manusia yang berkualitas, khususnya pada instansi pemerintahan di masa mendatang.

\section{Perumusan Masalah}

Berdasarkan uraian latar belakang diatas, dirumuskan masalah sebagai berikut :

1 Apakah terdapat pengaruh langsung antara efektivitas penempatan kerja terhadap kinerja pegawai ?

2 Apakah terdapat pengaruh langsung antarakarakteristikpekerjaan berpengaruh langsung terhadap motivasi berprestasi pegawai ?

3 Apakah terdapat pengaruh tidak langsung antara efektivitas penempatan kerja dan karakteristik pekerjaan terhadap kinerja pegawai melalui variabel intervening motivasi berprestasi ?

\section{Tujuan Penelitian}

Adapun tujuan penelitian sebagai berikut

c. Untuk mengetahui dan menganalisis

pengaruh langsung efektivitas penempatan kerja terhadap kinerja pegawai.

d. Untuk mengetahui dan menganalisis pengaruh langsung karakteristik pekerjaan terhadap motivasi berprestasi pegawai.

e. Untuk mengetahui dan menganalisis pengaruh tidak langsung efektivitas penempatan kerja dan karakteristik pekerjaan terhadap kinerja pegawai melalui variabel intervening motivasi berprestasi.

\section{TINJAUAN KEPUSTAKAAN Peneliti Terdahulu}

g. Isdarmadi (2002) judul Pengaruh Efektivitas Penempatan Pegawai, Motivasi Berprestasi dan Gaya Kepemimpinan Terhadap Kinerja Pegawai Pada Kantor Sekretariat Daerah Kabupaten Kudus. Hasil

penelitian menyatakan Terdapat hubungan positif dan signifikan antara efektivitas penempatan pegawai, motivasi berprestasi, dan gaya

kepemimpinan terhadap kinerja pegawai.

h. Asmoro (2009) judul Hubungan Motivasi Berprestasi Dan Iklim Organisasi Dengan Kinerja Penyuluh Kehutanan Terampil. Hasil penelitian menyatakan a) Tidak terdapat 
hubungan antara motivasi berprestasi dengan kinerja Penyuluh Kehutanan Terampil, b) Terdapat hubungan nyata iklim organisasi dengan kinerja Penyuluh Kehutanan Terampil dan c) Terdapat hubungan antara motivasi berprestasi dan iklim organisasi dengan kinerja Penyuluh Kehutanan Terampil.

3. Restanto (2008) judul Kinerja Pegawai KPP Pratama Tebet Ditinjau dari Karakteristik Pekerjaan, Kreativitas, Kemandirian dan Kompetensi. Hasil penelitian menyatakan secara parsial menunjukkan bahwa terdapat hubungan positif dan signifikan antara karakteristik pekerjaan, kreativitas, kemandirian dan kompetensi terhadap kinerja pegawai.

4. Soares (2010) judul Pengaruh Penempatan, Karakteristik Pekerjaan Dan Lingkungan Kerja Terhadap Motivasi dan Kinerja Karyawan Grand Sinar Indah Hotel Kuta - Bali. Hasil

penelitian membuktikan bahwa penempatan, karakteristik pekerjaan dan lingkungan kerja berpengaruh signifikan terhadap motivasi dan kinerja karyawan Grand Sinar Indah Hotel Kuta-Bali. Juga terbukti bahwa motivasi berpengaruh signifikan.

\section{Uraian Teoritis Penempatan (Placement)}

Penempatan merupakan tahapan setelah proses rekrutmen dilaksanakan. Pada tahapan penempatan ini yang diharapkan organisasi ataupun instansi mampu mendapatkan jumlah dan kualitas kerja yang tepat dari pegawai. Penempatan pegawai harus dilaksanakan sesuai dengan ruang lingkup yang telah ditetapkan, serta mampu mempertanggungjawabkan segala resiko dan kemungkinan yang terjadi atas tugas dan pekerjaan, wewenang serta tanggung jawabnya. Penempatan pegawai

hendaknya memperhatikan azas penempatan orang-orang yang tepat dan penempatan orang tepat untuk jabatan yang tepat atau the right man in the right place and the right man behind the right job.

Berikutbeberapa definisi penempatan menurut beberapa sumber sebagai berikut : MenurutWidiyantoro (2012) penempatan kerja dimaksudkan yaitu untuk menempatkan tenaga kerja sebagai unsur pelaksana pekerjaan pada posisi yang sesuai dengan kemampuan, kecakapan, dan keahliannya.

Menurut Sulistiani dan Rosidah (2003), secara definitif penempatan pegawai adalah suatu kebijakan yang diambil oleh pimpinan suatu instansi, atau bagian personalia untuk menentukan seseorang pegawai masih tetap atau tidak ditempatkan pada suatu posisi atau jabatan fungsi tertentu.

Menurut Sastrohadiwiryo (2002) mengemukakan bahwa : Penempatan kerja adalah proses pemberian tugas dan pekerjaan kepada karyawan yang lulus seleksi untuk dilaksanakan sesuai ruang lingkup yang telah ditetapkan, serta mampu mempertanggungjawabkan segala resiko dan kemungkinan-kemungkinan yang terjadi atas tugas dan pekerjaan, wewenang serta tanggung jawab.

Mathis danJackson (2001), Penempatan adalah penempatan sesorang ke posisi pekerjaan yang tepat, hal ini difokuskan dengan kesesuaian dan pencocokan antara pengetahuan, keterampilan, dan kemampuan (knowledge, skill, and abilities) orangorang dengan karakteristik-

karakteristik pekerjaan.

\section{Karakteristik Pekerjaan}

Teori dalam karakteristik pekerjaan merupakan uraian karakteristik pekerjaan dari suatu pekerjaan tertentu. 
Konsepdari karakteristik pekerjaan didasari oleh adanya suatu pola pikir bagaimana cara membuat sesuatu memiliki sifat yang dapat meningkatkan peningkatan terhadap kemampuan kerja dan kepuasan kerja serta penurunan tingkat kemangkiran dan karakteristik pekerjaan tertentu, sesuai kebutuhan individu tentu dapat memberikan kepuasan pada proses selanjutnya dapat mempengaruhi motivasi kerja. Teori ini hanya melibatkan aspek pekerjaan yang berfungsi sebagai pendorong motivasi bagi individu yang mengerjakan suatu pekerjaan secara efektif dan efisien.

MenurutMorgesonand Humphrey(2006) mendefinisikan karakteristik pekerjaan sebagai cara yang dilakukan untuk menyelesaikan suatu pekerjaan serta cakupan pekerjaan yang diberikan. Menurut Gunastri (2009) karakteristik pekerjaan adalah sifat atau tugas yang meliputi tanggung jawab, macam tugas dan tingkat kepuasan yang dirasakan dari pekerjaan itu sendiri.

Pekerjaan yang secara instrinsik memberikan kepuasan akan lebih memotivasi bagi kebanyakan orang dan pada pekerjaan yang tidak memuaskan.

Menurut Restanto (2008) karakteristik pekerjaan merupakan dimensi inti pekerjaan yang berisi sifatsifat tugas yang ada dalam suatu pekerjaan. Menurut Restanto (2008) juga menegaskan bahwa karakteristik pekerjaan adalah atribut-atribut tugas bersifat yang ada dalam pekerjaan. Menurut Simamora (2004), karakteristik pekerjaan merupakan suatu pendekatanterhadappemerkayaan pekerjaan. Motivasi Berprestasi Secara umum motivasi adalah dorongan yang muncul dalam diri seseorang untuk berprilaku lebih baik

dalam mencapai sesuatu yang menjadi tujuannya. Motivasi mempersoalkan bagaimana caranya mendorong gairah kerja pegawai, agar mereka mau bekerja keras dengan memberikan semua kemampuan dan keterampilannya untuk mewujudkan tujuan organisasi. Apabila seorang pegawai tidak terpenuhi

kebutuhannya maka pegawai tersebut akan menunjukkan perilaku kecewa. Sebaliknya, jika kebutuhannya terpenuhi maka pegawai tersebut akan memperlihatkan perilaku yang positif sebagai manifestasi prestasi kerja yang maksimal. Pengertian motivasi berprestasi terus berkembang mengikuti dinamisnya pengetahuan dan wawasan sumber daya manusia Berikutinimpara ahli menjelaskan definisi motivasi berprestasi yaitu : Menurut

Munawaroh (2012) mendefinisikanmotivasi berprestasi sebagai motivasiyang mendorong seseorang untuk mencapai keberhasilan dalam bersaing dengan suatu ukuran keunggulan.

Menurut Asmoro (2009) "Motivation is a hypothetical constructused to explain the initiation, direction, intensity, and persistence of goal-directed behavior. It subsumes concepts such as need for achievement, need for affiliation, incentives (reward and punishment), habit, discrepancy, and curiosity".

Motivasi adalah suatu konsepsi hipotetis yang digunakan untuk menjelaskan konsep tentang inisiasi, arah, intensitas dan ketekunan individu mengarahkan perilaku. Konsep motivasi digolongkan pada kebutuhan untuk berprestasi, kebutuhan untuk berkelompok, sanksi (penghargaan atau hukuman), kebiasaan, kecurigaan/keingintahuan, dan pertentangan.

\section{Kinerja Pegawai}

Kinerja merupakan perbandingan hasil kerja yang dicapai oleh pegawai dengan standar yang telah ditentukan.Kinerja juga berarti hasil yang dicapai oleh pegawai dengan standar yang ditentukan.Kinerja juga berarti hasil yang dicapai oleh seseorang baik kuantitas maupun kualitas sesuai dengan tanggung jawab yang diberikan kepadanya. Kinerja seseorang dipengaruhi oleh tingkat pendidikan, inisiatif, pengalaman kerja dan motivasi 
pegawai. Hasil kerja seseorang akan memberikan umpan balik bagi orang itu sendiri untuk selalu aktif melakukan kerjanya secara baik dan diharapkan akan menghasilkan mutu pekerjaan yang baik.

Suharto dan Cahyono (2005) mendefinisikan kinerja sebagai hasil dari usaha seseorang yang dicapai dengan adanya kemampuan dan perbuatan dalam situasi tertentu. Kinerja menurut Flippo (2001) adalah "Hasil yang dicapai oleh seseorang dalam bidang pekerjaannya menurut kriteria tertentu yang berlaku untuk suatu pekerjaan tertentu dan dievaluasi oleh orang-orang tertentu". Selanjutnya oleh Flippo (2001) dikatakan bahwa "Seseorang agar mencapai kinerja yang tinggi tergantung pada kerja sama, kepribadian, kepandaian yang beraneka ragam, kepemimpinan, keselamatan, pengetahuan pekerjaan, kehadiran, kesetiaan, ketangguhan dan inisiatif.

AdapunmenurutSimamora

(2004),

kinerjaadalah

tingkat terhadapnyaParakaryawanmencapaipersyaratanpersyaratan pekerjaan. Sedangkan menurut Robbins (2007), kinerja adalah fungsi dari interaksi antara kemampuan dan inovasi. Jika ada yang tidak memadai kinerja akan dipengaruhi secara negatif, kecerdasan dan ketrampilan harus dipertimbangkan. Berdasarkan pendapat di atas dapat dilihat bahwa kinerja pegawai dipengaruhi oleh kerjasama, kepribadian, kepandaian yang beraneka ragam, kepemimpinan, keselamatan, pengetahuan pekerjaan, kehadiran, kesetiaan, ketangguhan dan inisiatif.

\section{Kerangka Konseptual}

Berdasarkan penjelasan secara teoritis dan didukung oleh hasil penelitian terkait mengenai efektivitas penempatan pegawai dan karakteristik pekerjaan terhadap kinerja pegawai dan menghubungkan pengaruh tidak nyata terhadap motivasi berprestasi, oleh karena itu, gambar kerangka konseptual guna menjadi dasar alur pikir penelitian ini sebagai berikut :

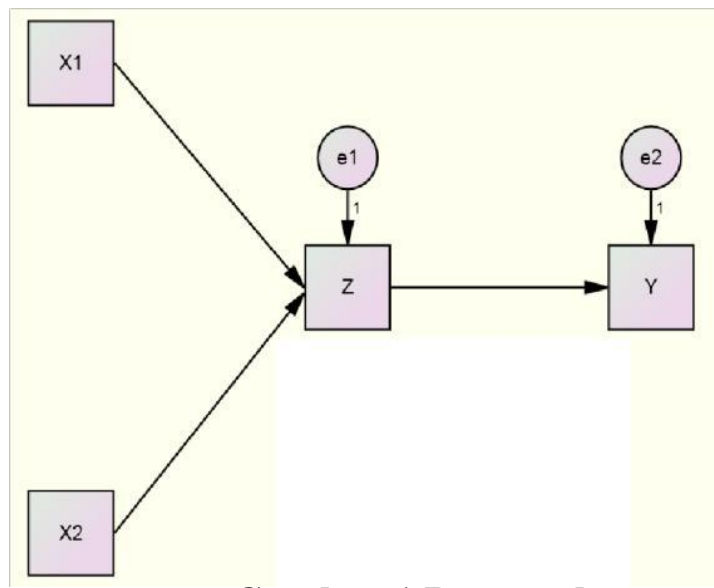

Gambar 1 Pengaruh

Tidak Langsung Antara X1dan X2Terhadap Y Melalui Variabel Intervening Z.

\section{Hipotesis Penelitian}

Berdasarkan uraian kerangka pemikiran, maka dapat diajukan hipotesis penelitian sebagai berikut :

1. Efektivitas penempatan kerja berpengaruh langsung terhadap kinerja pegawai.

2. Karakteristik pekerjaan berpengaruh langsung terhadap terhadap kinerja pegawai.

3. Efektivitas penempatan kerja dan karakteristik pekerjaan berpengaruh tidak langsung terhadap kinerja pegawai melalui variabel intervening motivasi berprestasi. 


\section{METODE PENELITIAN Jenis dan Sifat Penelitian}

Jenis penelitian yang akan digunakan dalam penelitian ini adalah jenis penelitian asosiatif, yaitu penelitian yang bersifat menanyakan hubungan antara dua variabel atau lebih dalam hal ini hubungan tersebut bersifat kausal, yaitu variabel bebas yang mempengaruhi variabel terikat. Menurut Istijanto (2010) menyatakan bahwa penelitiann yang bersifat kausal berguna untuk membuktikan hubungan mempengaruhi dan dipengaruhi dari variabelvariabel yang diteliti. Penelitian ini jenis ini umumnya menggunakan data kuantitatif yang dikumpulkan dengan metode pengumpulan data survey.

\section{Populasi}

Populasi adalah wilayah generalisasi yang terdiri atas objek atau subjek yang mempunyai kualitas dan karakteristik kemudian ditarik kesimpulan (Sugiyono, 2010). Populasi yang dimaksudkan dalam penelitian secara keseluruhan merupakan pegawai DinasPendidikan Kabupaten Labuhanbatu berjumlah 40 orang (pegawai). Adapun metodesamplingjenuh, yaitu teknik penentuan sampelapabila semua populasi digunakan sebagai sampel.

\section{Teknik Pengumpulan Data}

Dalam penelitian,teknik pengumpulan data merupakan faktor penting demi keberhasilan penelitian. Hal ini berkaitan dengan bagaimana cara mengumpulkan data, siapa sumbernya, dan apa alat yang digunakan angket (kuesioner) dari data primer dan data sekunder.

\section{Teknik Analisis Data}

Setelah dilakukan pengujian vailiditas dan reliabilitas, serta semua data yang diperoleh sudah reliabel dan valid, maka data dapat dianalisis lebih lanjut. Model analisis jalur digunakan untuk menganalisis pola hubungan antar variabel dengan tujuan untuk mengetahui hubungan pengaruh langsung maupun tidak langsung seperangkat variabel bebas (eskogen) terhadap variabel terikat (endogen). Model analisis jalur yang dibicarakan adalah pola hubungan sebab akibat atau " $a$ set of hypothesized causalasymetricrelation among the variables. 


\section{HASIL DAN PEMBAHASAN}

\section{Hasil Penelitian Path Analysis}

Sebagai tahap awal dari metode analisis jalur (Path Analysis), maka dibuat terlebih dahulu diagram jalur. Dari hasil pengolahan data dengan program AMOS diperoleh diagram jalur disertai koefisien jalur sebagai berikut :

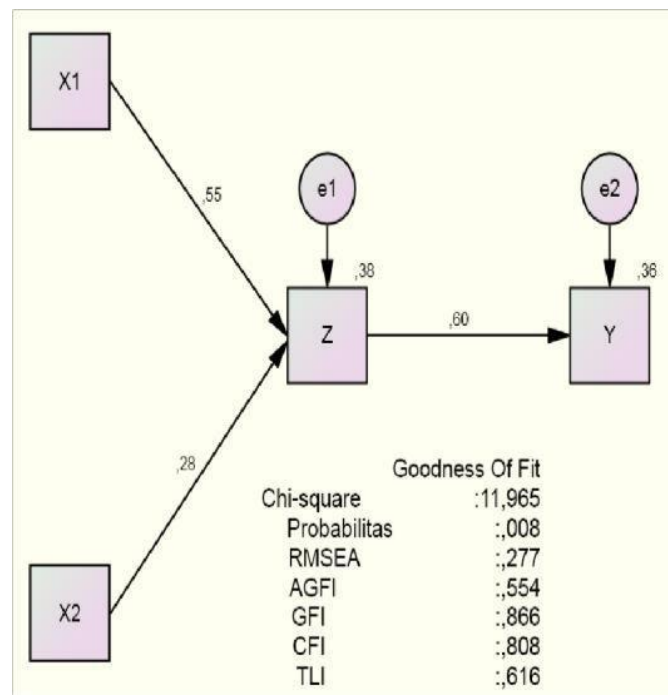

Gambar 2

Hasil Output Pengaruh Tidak Langsung Antara X1dan X2Terhadap Y Melalui VariabelIntervening $\mathbf{Z}$

Pengaruh tidak langsung di atas muncul koefisien jalur yang menunjukkan pengaruh tidak langsung antara efektivitas penempatan kerja dan karakteristik pekerjaan terhadap kinerja pegawai melalui variabel intervening motivasi berprestasi dapat dilihat pada Tabel 1 berikut:

\section{Tabel 1}

Koefisien Regresi (Standardized Regression

Weights)

\begin{tabular}{|l|l|l|}
\hline & $\begin{array}{l}\text { Estima } \\
\text { te }\end{array}$ \\
\hline $\begin{array}{l}\text { Motivasi } \\
\text { Berprestasi }\end{array}$ & $\begin{array}{l}\text { <--- Efektivitas } \\
\text { Penempatan Kerja }\end{array}$ & 0,549 \\
\hline $\begin{array}{l}\text { Motivasi } \\
\text { Berprestasi }\end{array}$ & $\begin{array}{l}\text { <--- Karakteristik } \\
\text { Pekerjaan }\end{array}$ & 0,281 \\
\hline $\begin{array}{l}\text { Kinerja } \\
\text { Pegawai }\end{array}$ & $\begin{array}{l}\text { <--- Motivasi } \\
\text { Berprestasi }\end{array}$ & 0,601 \\
\hline
\end{tabular}


Sumber : Hasil Penelitian, (2016)

Tabel 3

Regression Weight (Pengujian Hipotesis)

\begin{tabular}{|c|c|c|c|c|c|}
\hline & & Estimate & S.E. & C.R & $\mathrm{P}$ \\
\hline $\begin{array}{l}\text { Motiva } \\
\text { si } \\
\text { Berpres } \\
\text { tasi }\end{array}$ & \begin{tabular}{|l}
$<---$ \\
Efektivitas \\
Penempatan \\
Kerja
\end{tabular} & ,376 & ,086 & 4,356 & $* * *$ \\
\hline $\begin{array}{l}\text { Motiva } \\
\text { si } \\
\text { Berpres } \\
\text { tasi }\end{array}$ & $\begin{array}{l}\text { <--- } \\
\text { Karakteristi } \\
\mathrm{k} \\
\text { Pekerjaan }\end{array}$ & ,203 & ,091 & 2,233 & ,026 \\
\hline $\begin{array}{l}\text { Kinerja } \\
\text { Pegawa } \\
\text { i }\end{array}$ & $\begin{array}{l}\text { M--- } \\
\text { Motivasi } \\
\text { Berprestasi }\end{array}$ & ,746 &, 159 & 4,700 & $* * *$ \\
\hline
\end{tabular}

KESIMPULAN DAN SARAN

\section{Kesimpulan}

Berdasarkan pembahasan yang

telah dilakukan, dapat diambil kesimpulan sebagai berikut:

1. Efektivitas penempatan kerja berpengaruh langsung terhadap kinerja pegawai.

2. Karakteristik pekerjaan berpengaruh langsung terhadap kinerja pegawai.

3. Efektivitas penempatan kerja dan karakteristik pekerjaan berpengaruh tidak langsung terhadap kinerja pegawai melalui variabel intervening motivasi berprestasi. 


\section{DAFTAR PUSTAKA}

Asmoro,Hendro. 2009. Hubungan Motivasi Berprestasi dan Iklim Organisasi Dengan Kinerja Penyuluh Kehutanan Terampil (Kasus di Kabupaten Purwakarta dan Kabupaten Kuningan, Provinsi Jawa Barat). TesisSekolah PascasarjanaInstitut Pertanian Bogor.

Bangun, Wilson. 2012.ManajemenSumber Daya Manusia,Bandung.Erlangga.

Gunastri, Ni Made. 2009. Karakteristik Individu, Karakteristik Pekerjaan, Karakteristik Organisasi, Motivasi Kerja dan Kinerja Karyawan.Jurnal Forum Manajemen. Vol 7.No 1.

Isdarmadi. 2002. Pengaruh Efektivitas PenempatanPegawai, Motivasi Berprestasi dan Gaya Kepemimpinan Terhadap Kinerja Pegawai Pada Kantor Sekretariat

Daerah Kabupaten Kudus. Tesis Magister Administrasi Publik Program Pascasarjana Universitas Diponegoro.

Isfahani, Sakineh Saghaeiannejad, Soosan Bahrami, and Sedighe Torki. "Job Characteristic Perception and IntrinsicMotivation in

Medical RecordDepartment Staff." MedicalArchives 67(2013), 51-55. doi:10.5455/medarh.2013.67.51-55

Istijanto.2010. Riset Sumber Daya Manusia. Jakarta :PT Gramedia PustakaUtama.

Lee, Hung Wen. 2010. The Relationshipbetween Achievement Motivation and

Psychological Contract.Journal of Global Business Issue Spring 2010; 4, 1; pg 9.

Lyerand Kamalanabhan. 2006. Achievement

Motivation and Performance of Scientists in Researchand Development

Organizations.Journal of Scientist \& Industrial Research. Vol. 65, March 2006, pp. 187-194

Mathis, Robert L and Jackson John H. (Terjemahan Jimmy Sadeli dan

Bayu Prawira).2001. Manajemen Sumber Daya Manusia, jilid 1, Jakarta. Penerbit Salemba.

Morgeson, F. P., and Humphrey, S. E. 2006. The Work Design Questionnaire(WDQ): Developing and validating a comprehensive measure for assessing job design and the nature of work. Journal of

Applied Psychology, 91, 13211339.

Munawaroh, Azizatul. 2012. Program Intervensi Achievement

Penerbitan STIE YKPN. 1993-8233 C2011 Academic Soares, Aderito Babo. 2010. Pengaruh Journals. Penempatan, Karakteristik Widiyantoro, Yudy. 2012. Pengaruh Pekerjaan dan Lingkungan Kerja Seleksi, Penempatan Tenaga Terhadap Motivasi dan Kinerja Kerja DanPengembangan Karyawan Grand Sinar Indah Pegawai Terhadap koduktivitas Hotel Kuta - Bali. Tesis Program Kerja Pegawai Pada Inspektorat Pascasarjana Jurusan Kabupaten Kediri. Jurnal Ilmu Manajemen Universitas Manajemen, REVITALISASI, Udayana Vol. 1, Nomor 3, Desember

Sugiyono. 2010.Metode Penelitian 2012. Kuantitatif Kualitatif Dan $R \& D, \quad$ BandungAlfabeta.Suharto dan Budhi Cahyono. 2005. PengaruhBudaya 
Organisasi,Kepemimpinandan Motivasi KerjaTerhadap Kinerja Sumber DayaManusia di SekretariatDPRD Propinsi Jawa Tengah. Jurnal Riset \& BisnisIndonesia, Vol.1, No.1.

Suliyanto.2005. Analisis Data Dalam Aplikasi Pemasaran. Bogor: Glia Indonesia Anggota

IKAPI.

Sulistiyani. A. Teguh dan Rosidah.2003.Manajemen Sumber DayaManusia, Yogyakarta : Grahallmu.

Sultan,Sarwat. 2012. Examining the Job Characteristics: A Matter of Employees' Work Motivation and Job Satisfaction. Journal ofBehavioural Sciences, Vol. 22, No. 2,2012.

Tutar, et. al. 2011. The Effects Of Employee EmpowermentOn Achievement Motivation And The Contextual Performance Of Employees. African Journal ofBusiness Management Vol.

5(15), pp. 6318-6329, 4 August, 2011 Available online athttp://www.academicjournals.org/AJBM DOI: 